DOI: 10.34015/2523-4552.2020.1.06

УдК 343.101

Гумін О. М.,

доктор юридичних наук, професор,

завідувач кафедри кримінального права $i$

процесу Інституту права, психології та

інноваційної освіти Національного

університету «Львівська політехніка»

ORCID: 0000-0002-8016-945X

Якимова С. В.,

кандидат юридичних наук, доцент, доцент кафедри кримінального права $i$ процесу Інституту права, психології та інноваційної освіти Національного університету «Львівська політехніка» ORCID: 0000-0003-1440-5925

\title{
КРИМІНОЛОГІЧНІ ОСОБЛИВОСТІ ЗАПОБІГАННЯ РЕЦИДИВУ ЗЛОЧИНІВ НЕПОВНОЛІТНІХ
}

У статті з'ясовано місце, роль і значення запобігання рецидиву злочинів у системі запобігання злочинності неповнолітніх. Встановлено, що реалізація запобігання рецидиву неповнолітніх ускладнена тим, що об'єктом запобігання $€$ категорія дітей, які вже мають певний кримінальний досвід. Мета виправлення неповнолітнього розглядається як процес відновлення позитивного особистісного потенціалу засудженого неповнолітнього та закріплення його здатності протистояти можливим кримінальним загрозам.

Ключові слова: рецидив; злочини неповнолітніх; кримінологічні особливості; покарання; ресоціалізація.

В статье определены место, роль и значение предотвращения рецидива преступлений в системе предупреждения преступности несовершеннолетних. Установлено, что реализация предотвращения рецидива преступлений несовершеннолетних усложняется тем, что объектом предотвращения есть категория детей, которые уже имеют определенный криминальный опыт. Цель исправления несовершеннолетнего рассматривается как процесс восстановления его положительного личностного потенциала, а также закрепления способности противостоять возможным уголовным угрозам.

Ключевые слова: рецидив; преступления несовершеннолетних; криминологические особенности; наказание; ресоциализация.

Постановка проблеми. Кримінологічна проблематика пошуку оптимальних шляхів і засобів запобігання злочинам неповнолі- тніх ніколи не втрачала своєї актуальності. Це визначається низкою об'єктивних факторів. Так, зокрема, від того на скільки ефек- 
тивним буде цей вид юридичної практики багато в чому буде залежати ступінь суспільної небезпеки загальної злочинності в майбутньомy, а також її показники стійкості, активності й організованості. Адже, злочинність неповнолітніх - це своєрідний «резерв» злочинності майбутніх десятиліть. За уточненими даними А. А. Тайбакова, 53 \% професійних злочинців свій перший злочин учинили у віці 14-16 років; а відповідно $39 \%$ - у віці 17-18 років [1, с. 41].

Попри те, що частка неповнолітніх, які вчинили злочини повторно, відносно незначна (до прикладу, у 2019 році становила - 16,3\%). Однак ці дані не варто сприймати абсолютно. По-перше, даний рецидив стосується лише чотирьох років життя людини, тоді як по відношенню до осіб, які досягли 18 років - це десятки років життєвого шляху. По-друге, рецидиву злочинів неповнолітніх притаманна підвищена латентність. Значна частина злочинів вчиняються неповнолітніми до 14 років (нижня межа можливості притягнення неповнолітнього до кримінальної відповідальності), а ще більша їх частина на загал сприймаються як дитячі пустощі про які «не прийнято» повідомляти правоохоронним органам. Як наслідок, з такими дітьми не здійснюється ефективна виховнопрофілактична робота, що сприяє подальшому розвитку їх злочинної поведінки.

Ще однією, не менш важливою обставиною, що визначає актуальність обраної для дослідження тематики, є перспективність застосування заходів запобігання рецидиву саме щодо категорії неповнолітніх. На відміну від уже соціально сформованих, повнолітніх осіб, фахове застосування виховано профілактичних заходів до осіб, які не досягли 18 років, практично завжди досягає поставленої мети - усунення деформацій соціальної спрямованості особистості з метою недопущення вчинення злочинів у подальшому. 3 іншого боку, застосування уповноваженими суб'єктами заходів запобігання рецидиву злочинів неповнолітніх - $\epsilon$ вкрай відповідальним і складним завданням. Його ефективне вирішення можливе лише за умови набуття суб'єктами запобігання рецидиву злочинів неповнолітніх, достатніх знань і навичок щодо специфіки застосування форм, методів та заходів щодо даної категорії осіб 3 метою недопущення учинення ними злочинів у подальшому.

Дослідження специфіки запобігання рецидиву злочинів неповнолітніх дозволяє одержати нову кримінологічну інформацію, що має значення для удосконалення цього виду юридичної практики з метою недопущення вчинення злочинів особами, які не досягли 18 років.

Таким чином, викладене вище, обумовлює актуальність і важливість комплексного дослідження широкого кола питань, пов'язаних із запобіганням рецидиву злочинів неповнолітніх.

Аналіз останніх досліджень і публікацій. Окремі аспекти злочинної поведінки неповнолітніх розглядалися у наукових працях Ю.Антоняна, Ю. Ємця, А. Зелінського, Н. Карпова, Г. Риснюк та ін. Актуальні питання профілактики 3 девіантними підлітками досліджувалися у працях Р. Благути, А. Лобанова, Ю. Меркулової, $\quad$ В. Оржеховської, Д. Пономарєва, Т. Титаренка, М. Чуносова та ін., а зокрема щодо їх ресо- 
ціалізації - знайшли відображення у дослідженнях Я. Васильєва, Т. Зайко, С. Коробейникова, Д. Понамарьова, I. Саламатіна, I. Шамприленко, Н. Юзікова та ін.

Постановка завдання. Уточнити роль і значення запобігання рецидиву у системі кримінологічної протидії злочинам неповнолітніх. 3'ясувати характерні ознаки діяльності у напрямку недопущення вчинення злочинів неповнолітніми, які вже мають досвід злочинної поведінки. Узагальнити рекомендації щодо перспективних напрямів подальшого удосконалення практики запобігання рецидиву злочинів неповнолітніх в Україні.

Виклад основного матеріалу. Сучасна державна політика у напрямку запобігання злочинам неповнолітніх $€$ багатогранною та, зокрема охоплює: забезпечення дотримання гарантій захисту прав дитини, у тому числі на її належний фізичний, психологічний, соціальний й духовний розвиток, а також гуманне поводження з неповнолітніми, які вчинили злочини, їх соціальну інтеграцію; заходи виховного характеру щодо недопущення девіантної поведінки дітей; заходи правового характеру, у тому числі кримінально-правові щодо неповнолітніх, які вчинили злочини (штраф, громадські чи виправні роботи, арешт, позбавлення волі на певний строк) тощо.

Отже, запобігання злочинам неповнолітніх є невід'ємною та важливою складовою сучасної державної політики щодо дітей. Як особливий вид соціальної практики - це цілісна взаємоузгоджена діяльність, передусім, уповноважених на це суб'єктів, з метою недопущення вчинення злочинів неповнолітніми, а ï зміст за- лежить від ступня розвитку делінквентності особи, яка не досягла 18 років. На наше переконання, кримінологічне запобігання злочинам неповнолітніх, доцільно представити як процес, що складається 3 таких послідовних стадій:

рання профілактика - це діяльність, яка спрямована на оздоровлення мікросередовища й допомогу неповнолітнім, що опинилися в складних ситуаціях, несприятливих умовах життя і виховання та, зокрема до того часу, як дія негативних біологічних, психологічних, соціально-економічних, соціально-педагогічних, соціально-культурологічних та інших факторів спричинили певну деформацію їх соціальної спрямованості. Такі заходи мають на меті усунення криміногенних чинників, які сприяють деформації особистості неповнолітнього та дезадаптації його поведінки;

- безпосередня профілактика передбачає комплексну соціальноправову й виховну роботу з неповнолітніми, особистість яких уже зазнала певних деформацій під дією негативних зовнішніх впливів й, передусім, з боку найближчого оточення. На цьому етапі розвитку злочинної поведінки деформація особистості неповнолітнього $є$ такою, що проявляється у порушенні неповнолітнім норм моралі, правил співжиття, учиненні правопорушень незлочинного характеру;

відвернення можливості вчинення злочину неповнолітнім на стадії готування чи замаху - це, зокрема, заходи, що передбачають його схиляння до відмови від продовження підготовчих та інших дій щодо завершення вчинення злочину. При цьому, можливість притягнення до 
кримінальної відповідальності за менш тяжкий злочин, з тим, щоб запобігти вчиненню більш тяжкому злочину, також наділена певним потенціалом зниження рівня суспільної небезпеки поведінки неповнолітнього правопорушника;

- запобігання рецидиву передбачає застосування комплексу заходів щодо неповнолітніх, які раніше вже вчинили злочини з метою недопущення їх вчинення в подальшому. Особливістю виховнопрофілактичного впливу на неповнолітніх засуджених $\epsilon$ те, що така діяльність передбачає поєднання виховний впливу з каральним.

Реалізація запобігання рецидиву неповнолітніх ускладнена тим, що об'єктом запобігання $\epsilon$ категорія дітей, які вже мають певний кримінальний досвід. Їх підвищена дратівливість, збудженість, неврівноваженість доволі часто призводить до порушення режиму відбування покарання. Некритичне ставлення до своїх учинків, неадекватна оцінка дійсності, моральна нестійкість неповнолітніх засуджених істотно знижують ефективність соціальної регуляції їх поведінки, ускладнюють формування суспільно корисних установок, поглядів і переконань. Дотримання неформальних правил, норм асоціальної субкультури, в основі яких перебувають цінності, традиції, звичаї злочинного середовища, на фоні прагнення до самоствердження, доволі часто супроводжується протизаконними діями з боку неповнолітніх засуджених [2, с. 44].

Таким чином, у контексті профілактики з засудженими неповнолітніми до позбавлення волі на певний строк, корегуючий вплив на їх особистість варто ототожнювати з виправ- ним. Процес виправлення має базуватися на наведенні довірливих відносин й передусім з персоналом виховних колоній для неповнолітніх. Метою виправлення має стати відновлення (підтримка) позитивного особистісного потенціалу засудженого неповнолітнього. За змістом виправлення багато в чому ототожнюється 3 ресоціалізацією неповнолітнього та перш за все передбачає напрацювання особистісної установки на усунення особистісних хиб і недоліків, оволодіння правилами співжиття та базовими загальнолюдськими цінностями. Наступним кроком має стати набуття знань, підвищення освітнього та культурного рівня засудженого неповнолітнього, виховання почуття відповідальності за свої вчинки, доручені справи, розвиток суспільно корисної ініціативи, самоповаги, а також упевненості й зацікавленості у можливості зміни своєї подальшої поведінки 3 девіантної на суспільно схвальну. На завершальному етапі запобігання рецидиву злочинів неповнолітніх має передбачати працевлаштування засудженого та/чи його повернення в освітній заклад, призначення персонального шефства (поручителя), надання матеріальної допомоги [3, с. 28-31].

У юридичній літературі запобігання рецидиву, у тому числі неповнолітніх, зазвичай, розглядається крізь призму призначення, виконання й відбування покарання, а також невідворотності, неминучості його застосування [4, с. 22]. Разом 3 тим, результати численних наукових досліджень доводять, що кримінальне покарання щодо неповнолітніх, володіє значно меншим профілактичним потенціалом, а ніж щодо дорослих [5, с. 13]. Передусім, це стосуєть- 
ся призначення неповнолітнім покарання у виді позбавлення волі на певний строк. Так, за даними окремих досліджень встановлено, що 68 \% неповнолітніх, які потрапляють у місця позбавлення волі, в подальшому знову вчиняють злочини [6]. Окрім цього, зростанню рецидиву злочинів неповнолітніх сприяє неналежна організація системи ресоціалізації неповнолітніх, які повернулися з виховних колоній. Натомість призначення заходів примусово-виховного характеру, не пов'язаних з ізоляцією неповнолітнього, навпаки, сприяє зниженню рівня рецидиву їх злочинної поведінки. Разом 3 тим, Н. П. Мелешко, досліджуючи ефективність покарання щодо неповнолітніх делінквентів, дійшов висновку про неефективність застосування до неповнолітнього таких видів покарань як штраф, оскільки стягнення коштів відбувається 3 батьків, тоді як неповнолітні практично залишаються безкарним; а також - скерування неповнолітніх у професійні училища соціальної реабілітації. Через недоліки їх діяльності 89 \% з числа таких підлітків у подальшому вчиняють злочини [7, с. 112].

На противагу цьому неповнолітні щодо яких у процесі реалізації правосуддя були апробовані відновні технології, у десять разів менше допускають рецидив злочинів [8].

Метою заходів запобігання рецидиву злочинів неповнолітніх має стати закріплення в їх особистості здатності й навичок протистояти процесу засвоєння попереднього досвіду кримінальної поведінки, а також перешкоджання можливості його подальшого розвитку.

За результатами психологічних досліджень встановлено, що форму- вання здатності у неповнолітнього протистояти вже набутому кримінальному досвіду сприятиме розвиток розсудливості, набуття навичок раціонально й 3 користю планувати свій вільний час, правильно визначати активний простір, вміло розпоряджатися власними коштами, вироблення комунікативних якостей, уміння налагоджувати стосунки у конфліктних ситуаціях, розвиток здатності зважати на права й інтереси інших осіб, виконуючи накази авторитетної особи не намагатися бездумно їх наслідувати, вміння визначати перспективи свого розвитку, виховання старанності, розмірковувати над сенсом життя [9, с. 16].

Удосконалення кримінологічного запобігання рецидиву злочинів неповнолітніх варто здійснювати у таких напрямках: забезпечення повноти виявлення та обліку неповнолітніх, які раніше вчиняли злочини або суспільно небезпечні діяння до досягнення віку кримінальної відповідальності; покращення якості та скорочення термінів розслідування та судового розгляду кримінальних проваджень щодо неповнолітніх; в процесі реалізації правосуддя активніше впроваджувати відновні технології; активізувати діяльність уповноважених підрозділів Національної поліції щодо виявлення й своєчасного припинення випадків, коли дорослі втягують неповнолітніх у злочинну діяльність; відродження практики закріплення громадських вихователів за неповнолітніми, які вчинили злочини; зобов'язати суддів, які призначають неповнолітньому міру покарання, не пов'язану з позбавленням волі, вимагати від батьків неповнолітніх працевлаштування останніх або відновлення їх навчан- 
ня у відповідному професійному чи загальноосвітньому закладі [10, c. 20-23].

Отже, кримінологічне запобігання рецидиву злочинів неповнолітніх $\epsilon$ багатогранною юридичною практикою, вимагає індивідуального підходу з урахуванням ступеня деформації особистості неповнолітнього, його домінуючих рис характеру, особливостей найближчого побутового оточення.

Висновки. Особливості реалізації кримінологічного запобігання рецидиву злочинів неповнолітніх, передусім, пов'язані зі специфічними особистісними характеристиками неповнолітнього, у зв'язку 3 набуттям ним певного злочинного досвіду, а також поєднанням заходів виховного й карального впливу. Корегуючий вплив на засудженого неповнолітнього багато в чому ототожнюється з процесом його ресоціалізації. Запобігання рецидиву злочинів неповнолітніх, як особливий вид соціальної практики, можна представити як процес, що складається зі стадій: a) напрацювання установки на виправлення поведінки, набуття навичок дотримання правил співжиття, засвоєння основних загальнолюдських цінностей; б) підвищення особистого освітнього й культурного рів- ня, підтримання й збереження фізичного й психічного здоров'я, формування добросовісного ставлення до праці, інша підтримка чи відновлення особистісного потенціалу неповнолітнього; в) формування й закріплення здатності протистояти можливим негативним впливам кримінального середовища, сприяння у працевлаштуванні, запровадження шефства (поручительства), інші заходи постпенітенціарного супроводу. у напрямку удосконалення запобігання рецидиву злочинів неповнолітніх доцільно активніше залучати громадськість в якості шефівнаставників (поручителів); у системі заходів кримінально-правового впливу в більшій мірі практикувати застосування покарань, що не пов'язані з ізоляцією неповнолітнього від суспільства; в процесі реалізації правосуддя частіше застосовувати відновні технології щодо неповнолітніх; розвивати партнерсько-педагогічні відносини між представниками виховних колоній і неповнолітніми засудженими в цілях успішної ресоціалізації останніх й недопущення вчинення злочинів у майбутньому тощо. Кожен з окреслених напрямів заслуговує на окреме вивчення та дослідження у подальших наукових працях.

\section{Список використаних джерел}

1. Тайбаков А. А. Проблемы предупреждения и профилактики корыстной преступности: учебное пособие. Петрозаводск : Изд-во Петрозаводского гос. ун-та, 2000. $51 \mathrm{c}$.

2. Зайко Т. М. Меры борьбы с преступностью несовершеннолетних и молодежи: правовой и психолого-криминологический аспекты: монография. Тамбов : 000 «Консалтинговая компания Юком», 2017. 85 с.

3. Белослудцев В. И. Педагогические основы исправления осужденных к длительным срокам лишения свободы: автореф. дис. на соискание ученой степени доктора педагогических наук: 13.00.01. Челябинск, 2000. 44 с.

4. Бандурка I. О. Протидія злочинам неповнолітніх як форма кримінальноправового захисту прав дітей. Форум права. 2014. № 1. С. 19-23. 
5. Попандопуло В. В. Преступность несовершеннолетних: состояние, функции, последствия, социальный контроль: автореф. дис. на соискание ученой степени кан. юрид. наук: 12.00.08. Краснодар, 2007. 20 с.

6. Наталія Бернацька Україна презентувала досягнення у сфері правосуддя для дітей на всесвітньому форумі. URL: https://dejure.foundation/news/ukraina-navsesvitniomu-kongresi-z-pravosuddia-dlia-ditey (дата звернення: 15.02.2020).

7. Ювенальная юстиция в Российской Федерации: криминол. проблемы развития / Н. П. Мелешко и др. Санкт-Петербург : Юрид. центр Пресс, 2006. 787 с.

8. Применение восстановительных технологий снизило рецидив преступлений у несовершеннолетних. Комерсантъ. 2019. 25 июн. URL: https://www.kommersant.ru/ doc/4011967 (дата звернення: 16.02.2020).

9. Кіраль А. Й. Формування здатності до криміналізації особистості підлітка неповнолітнього : автореф. дис. на здобуття наук. ступеня кандидата педагогічних наук: 19.00.07. Київ, 2018. 20 с.

10. Лелеков В. А. Преступный рецидив несовершеннолетних и его предупреждение. Вестник Воронежского института МВД России. 2014. № 4. С. 15-23.

\section{References}

Taibakov, A. A. (2000). Problemb preduprezhdenyia y profylaktyky korbstnoi prestupnosty: uchebnoe posobye [Problems of prevention and prevention of mercenary crime: a training manual]. Petrozavodsk: Yzd-vo Petrozavodskoho hos. un-ta [in Russian].

Zaiko, T. M. (2017). Meri borbi s prestupnostiu nesovershennoletnykh y molodezhy: pravovoi y psykholoho-krymynolohycheskyi aspekti [Measures to combat crime of minors and youth: legal, psychological and criminological aspects]. Tambov: 000 «Konsaltynhovaia kompanyia Yukom» [in Russian].

Belosludtsev, V. Y. (2000). Pedahohycheskye osnovы yspravlenyia osuzhdennыkh $k$ dlytelnыm srokam lyshenyia svobodu [The pedagogical basis for the correction of persons sentenced to long terms of imprisonment] (Avtoref. dys. na soyskanye uchenoi stepeny doktora pedahohycheskykh nauk). Cheliabynsk [in Russian].

Bandurka, I. O. (2014). Protydiia zlochynam nepovnolitnikh yak forma kryminalnopravovoho zakhystu prav ditei [Protidia zlochinam nepovnolitnyh yak form of criminal legal zahist rights of children]. Forum prava, 1, 19-23 [in Ukrainian].

Popandopulo, V. V. (2007). Prestupnost nesovershennoletnykh: sostoianye, funktsyy, posledstvyia, sotsyalnui kontrol [Juvenile delinquency: state, functions, consequences, social control] (Avtoref. dys. na soyskanye uchenoi stepeny kan. yuryd. nauk) Krasnodar [in Russian].

Bernatska, Nataliia. Ukraina prezentuvala dosiahnennia u sferi pravosuddia dlia ditei na vsesvitnomu forumi [Ukraine presented access to the sphere of justice for children at the All-Holy Forum]. URL: https://dejure.foundation/news/ukraina-na-vsesvitniomu-kongresiz-pravosuddia-dlia-ditey (data zvernennia 25.02.2020) [in Ukrainian].

Kiral, A. Y. (2018). Formuvannia zdatnosti do kryminalizatsii osobystosti pidlitka nepovnolitnoho [Formal health to criminal specialties: non-compliant]. (Avtoref. dys. na zdobuttia nauk. stupenia kandydata pedahohichnykh nauk). Kyiv [in Ukrainian].

Lelekov, V.A. (2014). Prestupniy retsydyv nesovershennoletnykh y eho preduprezhdenye. Vestnyk Voronezhskoho ynstytuta MVD Rossyy [Criminal relapse of minors and its prevention]. Bulletin of the Voronezh Institute of the Ministry of Internal Affairs of Russia, 4, 15-23 [in Russian]. 
o. Humin, Doctor of Law, Professor, Head of Department of Criminal Law and Process of the Lviv Polytechnic National University

ORCID: 0000-0002-8016-945X

S. Yakymova, Candidate of Law, Associate Professor, Associate Professor of the Department of Criminal Law and Process of the Lviv Polytechnic National University ORCID: 0000-0003-1440-5925

\section{Criminological particularities of prevention of repeated crimes by minors}

The article explores the criminological features of preventing the recurrence of juvenile crimes. It is substantiated that the increase in the recurrence of juvenile crimes further increases the public danger of general crime, affects its indicators of resilience, activity and organization. Emphasis is placed on the increased latency of recidivism of juvenile crimes, as well as the complexity, importance and prospect of applying measures to prevent recidivism in relation to the category of minors. The place, role, and importance of preventing crime recurrence in the juvenile delinquency system have been clarified.

One of the peculiarities of the implementation of the prevention of the recurrence of juvenile crimes is the combination of educational and punitive influence on convicts. The implementation of the prevention of juvenile recurrence is complicated by the fact that the object of prevention is the category of children who already have some criminal experience.

The significance of punishment in the system of measures of prevention of repeated juvenile crimes is analyzed. It has been confirmed that criminal penalties against minors, and in particular in the form of imprisonment, have significantly less preventive potential than for adults.

It has been proved that the process of correction should be based on establishing the trusting relations of the convicted juveniles with the staff of correctional colonies. The meaning of the correction is in many ways equated with the resocialization of the minor and involves the development of a facility to eliminate personal defects and shortcomings, mastering the rules of cohabitation and basic human values. The purpose of correcting a minor is seen as the process of restoring the positive personal potential of a convicted minor and consolidating his or her ability to withstand possible criminal threats in the future.

In the direction of improving the prevention of the recurrence of juvenile crimes, it is considered advisable to involve the public more actively as chief mentors (guarantors); in the criminal justice system, preference should be given to the use of penalties not related to the isolation of a minor from society; in the implementation of justice, more frequently use the technology of juveniles; to develop partnership-pedagogical relations between representatives of correctional colonies and juvenile prisoners in order to successfully re-socialize the latter and prevent future crimes, etc.

Keywords: relapse; juvenile crimes; criminological features; stages; directions; measure; corrections; punishments; re-socialization. 